\title{
A geographical error
}

The most suitably qualified person should secure an important post, in almost all instances. But competing interests among nations mean that this is not always the case in Europe.

TTher he poster most likely to be found hanging in the offices of large European organizations is not a picturesque Alpine view, but rather a version of a much-loved cartoon known as 'European hell', in which the British are the cooks, the French are the mechanics, the Germans are the lovers, and everything is organized by the Italians. This gentle mockery of national stereotypes conceals a much more true-to-life hell of the European bodies themselves, as they try to function efficiently while being politically beholden to national interests. Too often, key appointments in European organizations, including those related to science, are made on the basis of nationality rather than merit.

This sometimes means that the most competent person to head a department will be passed over if a compatriot happens to head an unrelated department in the same organization. It is usual for countries to put forward their own candidates and although few of these will be outright incompetent, more than a few will owe their candidature more to political circumstance than to expertise. So the right person for a particular job might be the wrong nationality. And the candidate with the right nationality may well be the wrong person.

Take, for example, the European Space Agency, which now has 17 member states. It offers nine directorships, plus the position of director-general, each of which have four-year mandates. Things are organized so that the big contributors such as Germany and France will get, on average, two top posts; others such as Britain and Spain will get one each; and low contributors will only occasionally get a top position. At the end of the day, a brilliant Portuguese astrophysicist with experience - and proven skill — in managing big space-science projects is unlikely to be considered for the coveted post of director of science if the director of resources management is also Portuguese.

It's a similar situation at the European Commission, whose current constitution requires that each of the 27 member states has its own commissioner. There is no legal quota for positions below this level, but in practice a sharp eye is kept on the broad distribution of jobs, to avoid political problems developing. It is accepted that priority for the higher positions that become vacant will be given to people from the new member states such as Bulgaria and Romania, until a reasonable geographic distribution is re-established. But at least all commission staff must pass a tough series of exams, which ensures some general level of competence.

Horse trading of positions in European organizations is a tough business, and is usually conducted by representatives of national governments who do not necessarily have the interests of the organization in question at heart. One of the most striking examples of this is the 2003 decision of the state council of the European Patent Office to split the six-year presidency between two heavily promoted candidates - one from France, the other from Britain - because they couldn't decide which
"Too often, key appointments are made on the basis of nationality rather than merit." august nation to offend. With the European Patent Office struggling to adapt to a massively increased workload and to new information technologies, it was highly inappropriate to weaken its leadership in this way.

Those European organizations that do fundamental research are, fortunately, less touched by the political interference than some of their counterparts. Even so, the nationality of the director of CERN, the European particle-physics laboratory near Geneva, is taken very seriously by its member states. Heads of its scientific divisions are selected entirely on merit, however. The European Southern Observatory seems to be free from national bias: four of its seven directorgenerals have been Dutch.

The geographical carve-up of key European positions is unfortunately intrinsic to multigovernmental organizations. Scientists should be aware of this political reality and should pressure their governments to ensure, as a minimum, that only suitably qualified candidates are put forward for significant posts. That at least will ensure that those with the 'right' nationality are unlikely to be completely wrong for a particular job that is important to science.

\section{Safety clause}

\section{US research on bioweapons has expanded rapidly, without sufficiently transparent regulation.}

$$
\text { fe }
$$
$n$ the aftermath of the September 2001 terrorist attacks, the US federal government wasted no time in allocating large amounts of resources to build facilities for research into dangerous pathogens that might be used by terrorists as bioweapons. But it is now emerging that there are problems with the way some of these facilities operate, which suggests that the overall process has been poorly managed. These issues must be addressed before any further expansion goes ahead.

As construction of the first facilities got under way, some specialists were warning - at least privately - that many of the labs would lack people properly experienced in handling 'select agents', as microorganisms that could be used in bioweapons are now euphemistically called. Critics said that many of the institutions selected to host the labs lacked the capacity to manage the task.

Two weeks ago, these predictions seemed to come true. On 30 June, the Centers for Disease Control and Prevention (CDC) in Atlanta, Georgia, suspended research with select agents in five labs at Texas A\&M University in College Station. The university is home to a 